\title{
PENGETAHUAN DAN SIKAP TENAGA KESEHATAN DI 13 PUSKESMAS KOTA CIMAHI TENTANG PENGGUNAAN ALAT PELINDUNG DIRI PADA ERA COVID-19
}

(KNOWLEDGE AND ATTITUDE OF HEALTH PERSONNEL IN 13 CIMAHI CITY HEALTH CENTERS ABOUT THE USE OF PERSONAL PROTECTION EQUIPMENT IN COVID-19 ERA)

\author{
$\underline{\text { Anastasia Yani Triningtyas }^{1}, \text { Lutfhi Nurlaela }^{2} \text {, Henny Juliastuti }}{ }^{3}$, Astri Pradini ${ }^{4}$ \\ ${ }^{1}$ Departemen Ilmu Kesehatan Masyarakat, Fakultas Kedokteran, Universitas Jenderal Achmad \\ Yani, Cimahi, Jawa Barat, Indonesia \\ ${ }^{2}$ Departemen Parasitologi, Fakultas Kedokteran, Universitas Jenderal Achmad Yani, Cimahi, \\ Jawa Barat, Indonesia \\ ${ }^{3}$ Departemen Biokimia, Fakultas Kedokteran, Universitas Jenderal Achmad Yani, Cimahi, \\ Jawa Barat, Indonesia \\ ${ }^{4}$ Departemen Histologi, Fakultas Kedokteran, Universitas Jenderal Achmad Yani, Cimahi, \\ Jawa Barat, Indonesia
}

Email Korespondensi : yanianastasia2@gmail.com

\begin{abstract}
ABSTRAK
Pandemi COVID 19 sangat berdampak pada berbagai bidang kehidupan terutama di bidang kesehatan. COVID 19 sangat menular dari manusia ke manusia lainnya, sehingga proteksi amatlah penting. Membludaknya kasus ini tentu saja menimbulkan masalah terutama pengadaan alat pelindung diri (APD) bagi tenaga kesehatan (nakes) yang sangat minim. Cara menggunakan APD yang benar sangat berpengaruh terhadap angka penularan COVID 19. Penelitian ini merupakan penelitian deskriptif kuantitatif yang bertujuan untuk mengetahui pengetahuan dan sikap tentang penggunaan APD pada nakes di puskesmas yang ada di wilayah Kota Cimahi. Penelitian ini melibatkan 72 nakes secara langsung dalam penanganan COVID 19 di 13 puskesmas Kota Cimahi dalam contact tracing, pengambilan sampel swab, dan penanganan pasien COVID 19 yang datang ke puskesmas. Pengetahuan nakes tentang APD menunjukkan bahwa sebagian besar memiliki pengetahuan cukup baik (75\%) dan sikap positif $(63 \%)$. Pengetahuan yang masih kurang dipahami terutama penggunaan APD saat tatap muka pelacakan kontak, indikasi pemakaian APD, prosedur pemakaian APD level 3, dan APD pada pemeriksaan pasien dengan ISPA. Sikap yang masih perlu ditingkatkan adalah dalam pentingnya penerapan protokol kesehatan saat istirahat kerja, efektivitas proteksi penggunaan penutup sepatu, kesadaran tidak menurunkan masker ke bawah dagu saat makan, dan tetap memprioritaskan penggunaan APD yang tepat dibanding kenyamanan. Pengetahuan
\end{abstract}


Triningtyas, AY : Pengetahuan dan Sikap Tenaga Kesehatan..

dan sikap merupakan faktor predisposisi yang mendorong perilaku nakes dalam penggunaan APD. Pengetahuan dan sikap yang baik berpengaruh terhadap praktik penggunaan APD yang benar diharapkan dapat memberikan perlindungan yang optimal bagi nakes.

Kata kunci: alat pelindung diri, pengetahuan, sikap

\section{ABSTRACT}

The COVID-19 pandemic has had a profound impact on various areas of life, especially in the health sector. COVID-19 is highly contagious from human to human, so protection is very important. How to use personal protective equipment (PPE) correctly greatly affects the rate of transmission of COVID 19. This study is a quantitative descriptive study that aims to determine knowledge and attitudes about the use of PPE for health workers at health centers in the Cimahi City area. This study involved 72 health workers directly in handling COVID 19 in 13 Cimahi city health centers in contact tracing, swab sampling, and handling COVID 19 patients who came to the puskesmas. Health workers' knowledge of PPE shows that most of them have quite good knowledge (75\%) and a positive attitude (63\%). Knowledge that is still poorly understood, especially the use of PPE during face-to-face contact tracing, indications for the use of PPE, procedures for using PPE level 3, PPE in examining patients with ARI. Attitudes that still need to be improved are the importance of implementing health protocols during work breaks, the effectiveness of protecting the use of shoe covers, awareness of not lowering the mask under the chin while eating, and prioritizing the use of appropriate PPE over comfort. Knowledge and attitudes are predisposing factors that encourage the behavior of health workers in the use of PPE. Good knowledge and attitudes affect the correct use of PPE, which is expected to provide optimal protection for health workers.

Keywords: attitude, knowledge, personal protective equipment

\section{PENDAHULUAN}

Ikatan Dokter Indonesia (IDI) mencatat, sejak Maret sampai Desember 2020, terdapat 504 tenaga kesehatan meninggal karena COVID-19. ${ }^{1}$ Pada masa pandemik COVID 19 ini, peran praktik pencegahan dan pengendalian infeksi dengan menggunakan alat pelindung diri (APD) amatlah penting, terutama bagi tenaga kesehatan yang bekerja di lini terdepan penapisan dan pemeriksaan baik diagnostik maupun klinis. Pada kenyataannya, masih banyak pekerja yang kurang memperhatikan keselamatan dan kesehatan untuk diri sendiri dan juga institusi terkait. $^{2}$

Menurut survei di RSUD Maria Walanda Maramis, terdapat beberapa komponen kesehatan dan keselamatan kerja (K3) yang belum terlaksana dengan baik yaitu APD yang belum dipergunakan sesuai dengan fungsinya. Alasan tidak digunakannya APD adalah malas, repot, tidak terbiasa, atau lupa. Hal ini sangat berkaitan dengan kesadaran dan perilaku petugas dalam menggunakan APD. 
Triningtyas, AY : Pengetahuan dan Sikap Tenaga Kesehatan..

Kemungkinan lain karena rendahnya pemahaman dan pengetahuan petugas terhadap bahaya yang akan timbul. ${ }^{3}$ Faktor lain yang memengaruhi penggunaan APD antara lain usia, pengalaman kerja, persepsi, lingkungan kerja, jam kerja, shift kerja, beban kerja, sifat pekerjaan, komunikasi, manajemen, sikap motivasi, pengetahuan. Jenis APD yang digunakan oleh tenaga kesehatan antara lain sarung tangan, masker, pelindung wajah, pakaian pelindung, apron, dan sepatu boot. Ketika petugas tidak menggunakan APD, risiko potensi terpapar penyakit atau terjadi kecelakaan kerja akan meningkat, hal ini sudah terjadi sebelum pandemi COVID19. ${ }^{3,4}$ Di era pandemi COVID-19 telah terdapat peningkatan tingkat kepatuhan pemakaian APD oleh tenaga kesehatan. Penelitian pada tenaga kesehatan di Instalasi Bedah Sentral RSUP Prof. Dr. R. D. Kandou Manado menunjukkan bahwa perawat yang patuh sebanyak $62,9 \% .^{5}$ Walaupun telah terjadi peningkatan kepatuhan dalam penggunaan APD selama pandemi, tetapi hal ini perlu terus ditingkatkan sehubungan risiko penularan dan virulensi COVID-19 yang sangat tinggi.

Puskesmas sebagai ujung tombak pelayanan primer bagi masyarakat, melaksanakan upaya penapisan serta penatalaksanaan pasien dengan dan tanpa gejala COVID 19. Dalam menjalankan tugasnya, seorang petugas di puskesmas tentu saja harus menggunakan APD yang sesuai dengan tugasnya masing-masing. Dalam pelaksanaannya masih banyak petugas yang tidak memakai APD sesuai dengan level keamanan yang dianjurkan. Hal ini kemungkinan karena kurangnya kesadaran para petugas serta ketersediaan APD yang memadai. Hal yang mempunyai pengaruh cukup besar terhadap penggunaan APD antara lain pengetahuan, dan sikap. ${ }^{5}$ Tujuan penelitian ini untuk mengetahui pengetahuan dan sikap tenaga kesehatan di 13 puskesmas yang ada di Kota Cimahi tentang penggunaan Alat Pelindung Diri pada masa COVID 19.

\section{BAHAN DAN METODE}

Jenis penelitian yang digunakan adalah deskriptif kuantitatif dengan menggunakan pendekatan cross sectional. Responden pada penelitian ini adalah 72 orang tenaga kesehatan yang bertugas secara langsung dalam penanganan COVID 19 di 13 puskesmas Kota Cimahi baik dalam, contact tracing, pengambilan sampel swab, maupun penanganan pasien COVID-19 pada Bulan Desember 2020. Pengambilan sampel dilakukan dengan cara purposive sampling.

Pengumpulan data primer dilakukan dengan pengisian secara mandiri kuesioner dengan menggunakan platform online 
Triningtyas, AY : Pengetahuan dan Sikap Tenaga Kesehatan..

(google form) oleh petugas kesehatan. Kuesioner terdiri dari 3 bagian yaitu identitas responden, pengetahuan, dan sikap tentang penggunaan APD.

Pengetahuan tentang penggunaan alat pelindung diri yaitu apa yang diketahui tenaga kesehatan tentang APD pada saat bekerja sesuai SOP yang telah ditetapkan Kementerian Kesehatan RI di berbagai seting pelayanan. Pengukuran variabel ini menggunakan skala modifikasi Gutman, apabila responden memberikan jawaban benar responden diberi skor 1, jawaban salah dan tidak tahu diberi skor 0 . Selanjutnya pengetahuan dikategorikan menjadi 2 kelompok yaitu cukup baik dan kurang baik.

Variabel sikap dalam penelitian adalah berupa pendapat seorang petugas kesehatan mengenai penggunaan APD. Variabel ini menggunakan skala Likert, sesuai jumlah pertanyaan dengan menggunakan 5 kategori yang diberi skor pada masing-masing jawaban. Adapun kategori pengelompokan sikap dibagi menjadi sikap positif dan negatif.

Data pengetahuan dan sikap yang telah dikumpulkan selanjutkan diolah dan dianalisis secara univariat dalam bentuk distribusi frekuensi (persentase).
Selanjutnya disajikan dalam bentuk tabel dan grafik.

\section{HASIL DAN PEMBAHASAN}

Berdasarkan Tabel 1 karakteristik responden yang ditampilkan adalah jenis kelamin, pendidikan profesi, latar belakang pendidikan terakhir, dan tugas dalam pelayanan puskesmas. Sebagian besar responden berjenis kelamin perempuan, berprofesi sebagai dokter/dokter gigi dan perawat, dengan latar belakang pendidikan diploma atau $\mathrm{S} 1$, bertugas di Balai Pengobatan/Poliklinik, skrining / pengambilan sampel, sebagian juga bekerja di Poliklinik KIA dan laboratorium. Petugas puskesmas secara bergantian bertugas saat pemeriksaan pelacakan kontak, pengambilan sampel swab, dan pemeriksaan/pengobatan dalam penanganan COVID-19. Pendidikan dapat menjadi salah satu faktor yang memengaruhi pengetahuan. ${ }^{6}$ Pendidikan tinggi dapat memengaruhi pola pikir tenaga kesehatan tetapi perlu dilakukan update informasi tentang standar protokol penggunaan APD terkini, sehingga pendidikan berkelanjutan menjadi solusi pamungkas untuk meningkatkan pengetahuan tenaga kesehatan. 
Triningtyas, AY : Pengetahuan dan Sikap Tenaga Kesehatan..

Tabel 1 Distribusi karakteristik responden

\begin{tabular}{|c|c|c|}
\hline Karakteristik Petugas & $\mathbf{n}$ & $\%$ \\
\hline \multicolumn{3}{|l|}{ Jenis Kelamin: } \\
\hline - Laki-laki & 2 & 2.8 \\
\hline - Perempuan & 70 & 97,2 \\
\hline \multicolumn{3}{|l|}{ Pendidikan Profesi : } \\
\hline - Dokter/Dokter gigi & 23 & 31.9 \\
\hline - Perawat/Perawat gigi & 22 & 30.6 \\
\hline - Bidan & 11 & 15.3 \\
\hline - Laboran/Analis & 16 & 22.2 \\
\hline \multicolumn{3}{|l|}{ Pendidikan terakhir: } \\
\hline - $\mathrm{S} 2$ & 4 & 5.6 \\
\hline - $\quad \mathrm{S} 1 / \mathrm{D} 4$ & 31 & 43.1 \\
\hline - $\quad \mathrm{D} 1 / \mathrm{D} 2 / \mathrm{D} 3$ & 37 & 51.4 \\
\hline \multicolumn{3}{|l|}{ Tugas dalam pelayanan puskesmas } \\
\hline $\begin{array}{l}\text { - Petugas skrining / pengambilan sampel } \\
\text { pemeriksaan }\end{array}$ & 20 & 27.8 \\
\hline - Balai Pengobatan/Poliklinik & 32 & 44.4 \\
\hline - Bagian KIA & 10 & 13.9 \\
\hline - Laboratorium & 10 & 13.9 \\
\hline
\end{tabular}

Perilaku dipengaruhi oleh tiga faktor yaitu faktor predisposisi (predisposing factor), mencakup pengetahuan, sikap, tindakan, sistem budaya, dan tingkat pendidikan. Faktor pemungkin (enabling factor), mencakup ketersediaan sarana dan prasarana yang mendukung pelayanan kesehatan dan faktor penguat (reinforcing factor) meliputi sikap petugas kesehatan, dan peraturan/kebijakan. ${ }^{6}$ Penelitian ini berfokus pada faktor predisposisi berupa pengetahuan dan sikap petugas kesehatan.

Kepatuhan tenaga kesehatan dalam menggunakan alat pelindung diri adalah perilaku sebagai seorang yang profesional terhadap suatu anjuran, prosedur atau peraturan yang harus dilakukan dan ditaati sesuai prosedur tetap (protap) yang telah ditetapkan sehubungan dengan penggunaan APD. Rendahnya perilaku kepatuhan terhadap penggunaan alat pelindung diri dapat berakibat pada keselamatan dan kesehatan tenaga kesehatan . Seorang tenaga kesehatan harus memperhatikan kepatuhan penggunaan APD di tempat kerja untuk meminimalkan risiko yang terjadi dan sebagai bentuk jaminan K3 saat melakukan tindakan prosedur medis. ${ }^{3}$

\section{Gambaran Pengetahuan tentang Penggunaan APD pada Petugas} Kesehatan di Puskesmas

Pengetahuan atau kognitif merupakan domain yang sangat penting dalam membentuk tindakan seseorang (overt behavior). Pengetahuan merupakan 
Triningtyas, AY : Pengetahuan dan Sikap Tenaga Kesehatan..

hasil dari pengamatan dan pengalaman individu terhadap suatu hal baru yang dapat berguna bagi individu tersebut. ${ }^{6}$

Sebagian besar petugas puskesmas memiliki pengetahuan yang cukup baik (75\%) seperti yang terlihat pada Gambar 1. Hasil ini lebih tinggi dibandingkan dengan penelitian yang dilakukan di Bantul Yogyakarta tahun 2017 pada perawat di Intensive Care Unit (ICU) RSUD Panembahan Senopati, 60\% responden memiliki pengetahuan tentang penggunaan
APD baik. ${ }^{7}$ Terdapat perbedaan tata kelola pasien pada saat pandemi dibandingkan pada umumnya. Kemampuan dan kesiapan tenaga Kesehatan dalam memberikan pelayanan kesehatan ditentukan oleh pengetahuan tenaga kesehataan . Pengetahuan tenaga Kesehatan di awal pandemi belum memadai karena terdapat perbedaan standar dan prosedur dalam memberikan pelayanan kesehatan pada saat pandemi dibandingkan sebelumnya. ${ }^{8}$

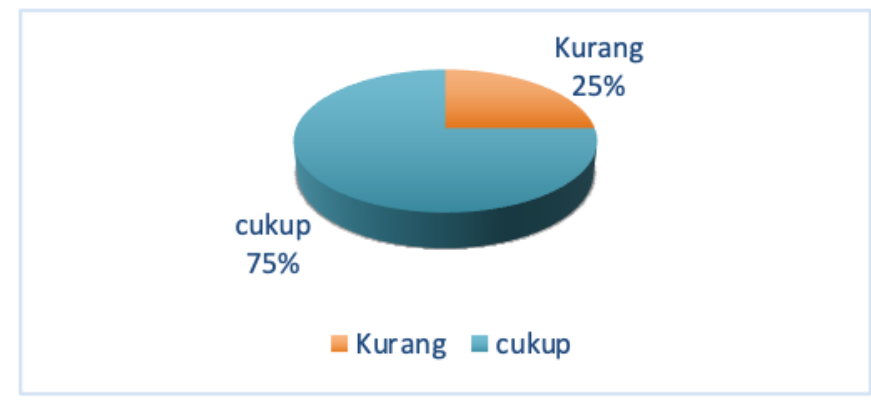

Gambar 1 Distribusi pengetahuan petugas kesehatan tentang APD pada penanganan COVID-19.

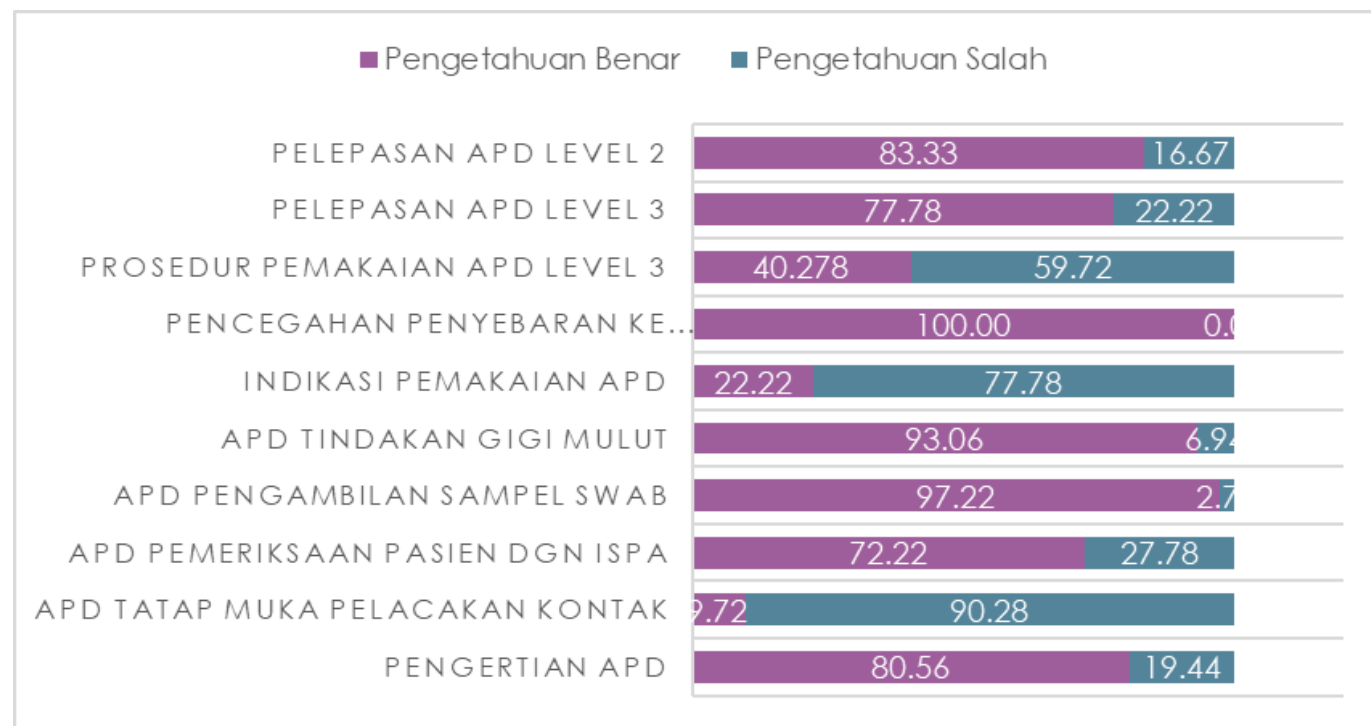

Gambar 2 Distribusi persentase jawaban benar pengetahuan tentang APD. 
Triningtyas, AY : Pengetahuan dan Sikap Tenaga Kesehatan..

Rincian pengetahuan digambarkan pada Gambar 2. Pengetahuan yang masih kurang dipahami responden terutama tentang APD yang digunakan saat tatap muka pelacakan kontak /contact tracing, indikasi pemakaian APD, prosedur pemakaian APD level 3, APD pada pemeriksaan pasien dengan ISPA, dan pelepasan APD level 3.

Berdasarkan Gambar 2 terdapat 90,3\% responden yang belum mengetahui penggunaan APD saat tatap muka pelacakan kontak /contact tracing . Pelacakan kontak / contact tracing adalah proses untuk mengidentifikasi, menilai dan mengelola orang-orang yang berkontak erat dengan kasus konfirmasi/probable untuk mencegah penularan selanjutnya. Kegiatan pelacakan kontak/contact tracing ini penting karena kasus konfirmasi dapat menularkan penyakit sejak 2 hari sebelum hingga 14 hari sesudah timbulnya gejala. Jika harus bertemu langsung, kegiatan wawancara sebaiknya dilakukan di luar ruangan/tempat dengan ventilasi baik/terbuka, menjaga jarak minimal 1 meter, menggunakan APD yang sesuai, dan pastikan orang yang diwawancara juga menggunakan masker medis. Pada kegiatan pelacakan kontak/contact tracing APD yang digunakan berupa masker medis dan pelindung wajah (face shield) untuk petugas dan masker medis untuk responden. ${ }^{9}$

Terdapat $59,7 \%$ responden yang belum memahami prosedur pemakaian APD level 3 dengan benar. Alat perlindungan diri level 3 merupakan APD yang digunakan oleh tenaga kesehatan dengan risiko infeksi terbesar. Salah satunya pada saat pengambilan sampel pernapasan (swab nasofaring dan orofaring) yang sering dilakukan oleh tenaga kesehatan di Puskesmas. Jenis APD yang digunakan terdiri dari: masker N95 atau ekuivalen, coverall/gown, boots/sepatu karet, pelindung sepatu, pelindung mata, face shield, sarung tangan karet steril sekali pakai, headcap, dan apron. $^{10}$

Pada penelitian ini pengetahuan yang kurang dipahami adalah pelepasan APD level 3. Hal ini sesuai dengan penelitian di Rumah Sakit Anak, Toronto, Kanada pada 175 tenaga kesehatan yang menyatakan bahwa $35 \%$ responden yang menunjukkan urutan melepas (doffing) APD yang benar sesuai rekomendasi peraturan, oleh karena itu institusi perawatan kesehatan harus mengadakan pelatihan berkelanjutan untuk petugas kesehatan. ${ }^{11}$

Pengetahuan adalah domain yang sangat penting untuk membentuk tindakan 
Triningtyas, AY : Pengetahuan dan Sikap Tenaga Kesehatan..

atau perilaku seseorang. Perilaku yang didasari pengetahuan akan lebih langgeng dibanding dengan perilaku yang tidak didasari pengetahuan. ${ }^{6}$ Semakin baik pengetahuan seseorang maka semakin baik pula tingkat kesadaran dan kedisiplinan seseorang dalam hal menerima atau menerapkan suatu pesan atau informasi yang disampaikan. Penelitian pada perawat bedah di IBS RSUD Ulin Banjarmasin, menunjukkan bahwa pengetahuan seseorang berpeluang lebih patuh 13,9 kali dibandingkan dengan yang berpengetahuan rendah. $^{12}$ Seorang tenaga kerja yang memiliki pengetahuan dan pemahaman baik tentang APD serta urgensi penggunaannya selama melaksanakan pekerjaan, akan memiliki tingkat kesadaran yang tinggi sehingga patuh dalam mengaplikasikan penggunaan APD dalam pekerjaan dan menciptakan budaya keselamatan. Terbentuknya budaya keselamatan melalui kepatuhan penggunaan APD diawali dari domain kognitif yang dimiliki tenaga kerja. ${ }^{13}$

$$
\text { Beberapa pengetahuan tentang }
$$
penggunaan alat pelindung diri masih kurang, membutuhkan pendidikan dan program pelatihan lebih lanjut. Penyegaran materi diperlukan terutama dalam penggunaan APD saat tatap muka pelacakan kontak serta prosedur pemakaian dan pelepasan APD level 3.

\section{Gambaran Sikap tentang APD pada}

\section{Petugas Kesehatan di Puskesmas}

Sikap merupakan keteraturan antara komponen-komponen pemikiran, hal perasaan dan merupakan predisposisi tindakan yang saling berinteraksi dalam memahami, merasakan, dan berperilaku terhadap suatu objek yang berada di sekitarnya Pada Gambar 3 ditunjukkan bahwa sebagian besar responden memiliki sikap cukup baik (63\%) dalam penggunaan APD pada penanganan COVID-19. Hal ini lebih rendah dibandingkan dengan penelitian pada tenaga kesehatan di Pakistan, responden yang memiliki sikap positif terhadap efektivitas penggunaan APD yang tepat (terutama masker) mencapai $88.5 \% .{ }^{14}$ Penelitian pada perawat RSUD Kanjuruhan Kepanjen Kabupaten Malang bahkan menunjukkan bahwa mayoritas responden mempunyai sikap yang positif terhadap penggunaan APD yang jauh lebih tinggi yaitu $95,35 \% .^{15}$ 
Triningtyas, AY : Pengetahuan dan Sikap Tenaga Kesehatan..

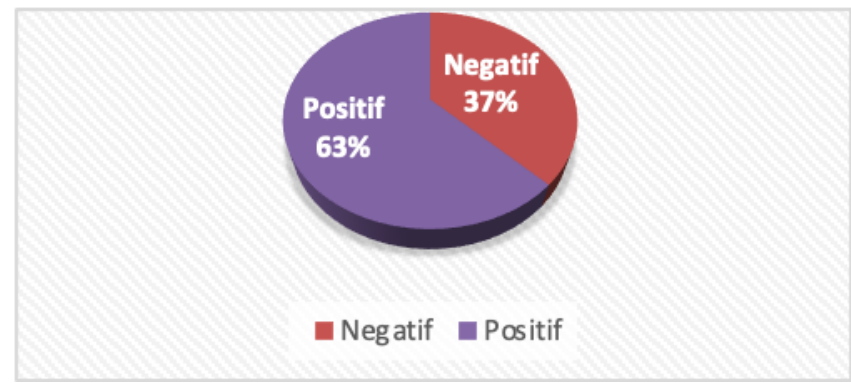

Gambar 3 Distribusi sikap petugas kesehatan tentang APD pada penanganan COVID-19.

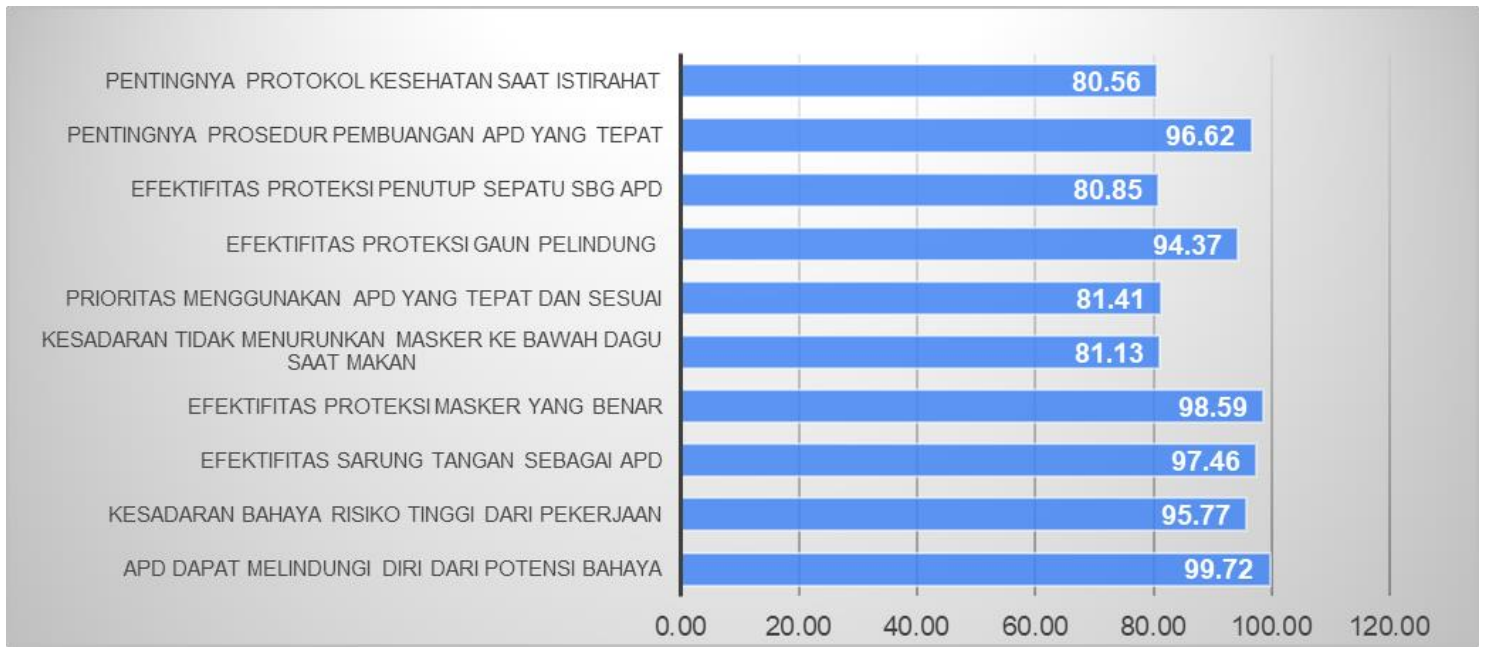

Gambar 4 Distribusi sikap positif petugas kesehatan dalam penggunaan APD pada penanganan COVID-19.

Dalam Gambar 4 diperlihatkan bahwa sikap yang masih perlu ditingkatkan adalah pentingnya konsistensi menerapkan kebiasaan baru protokol kesehatan saat istirahat kerja, kesadaran tidak menurunkan masker ke bawah dagu saat makan, efektivitas proteksi penularan dengan menggunakan penutup sepatu, tetap memprioritaskan penggunaan APD yang tepat dibandingkan kenyamanan.

Penggunaan masker merupakan bagian dari rangkaian tindakan pengendalian infeksi. Penggunaan masker yang kurang tepat akan memengaruhi perlindungan terhadap infeksi. Perilaku yang sering dilakukan adalah dengan menurunkan masker ke dagu saat seseorang makan/minum. Hal ini juga perlu diingatkan kembali pada tenaga kesehatan terutama saat mereka beristirahat makan/minum setelah bekerja di tempat kerja yang infeksius. Penelitian yang dilakukan terhadap 176 perawat dari tiga negara (60 perawat Jepang, 56 perawat Australia, 60 perawat China) menyatakan bahwa perawat dari negara berbeda 
Triningtyas, AY : Pengetahuan dan Sikap Tenaga Kesehatan..

memiliki berbagai keyakinan kesehatan tentang pemakaian masker dalam efficacy dan pada budaya menggunakan masker dalam kehidupan sehari-hari. Penggunaan masker yang tidak tepat dapat berperan dalam menyebabkan transmisi infeksi melalui masker. Selain itu penggunaan masker yang tidak benar akan menurunkan efektivitas perlindungan. ${ }^{14}$

WHO menganjurkan agar tenaga kesehatan yang memberikan layanan kepada pasien suspek atau terkonfirmasi COVID-19 memakai masker/ respirator selain alat pelindung diri yang merupakan bagian dari kewaspadaan standar, droplet (percikan), dan kontak. Respirator , N95 atau standar FFP2 atau FFP3 /setara digunakan apabila prosedur yang dilakukan berisiko terpapar aerosol. Masker medis dapat digunakan untuk prosedur pelayanan kesehatan lain yang tidak berisiko terpapar aerosol. Respirator dapat juga digunakan oleh tenaga kesehatan saat memberikan perawatan kepada pasien COVID-19 di lingkungan lain jika respirator tersedia dalam jumlah banyak dan biaya tidak menjadi masalah. Penggunaan, penyimpanan, dan pembersihan atau pembuangan masker jenis apa pun sangat penting untuk memastikan efektivitas terbaik masker dan untuk menghindari peningkatan risiko transmisi. ${ }^{16}$
Sikap merupakan reaksi atau respons yang masih tertutup dari seseorang terhadap suatu stimulus atau objek. Keadaan mental dan kesiapan yang diatur melalui pengalaman, memberikan pengaruh dinamik atau terarah terhadap respons individu pada semua objek dan situasi yang berkaitan dengannya. Sikap secara nyata menunjukkan konotasi adanya kesesuaian reaksi terhadap stimulus tertentu. $^{6}$

Penelitian pada perawat di RSUD Kabupaten Mamuju Tahun 2017 menunjukkan ada hubungan yang bermakna antara sikap dengan penggunaan APD. ${ }^{17}$ Penelitian lain pada tenaga kesehatan di Instalasi Bedah Sentral RSUP Prof. Dr. R. D. Kandou Manado juga menyimpulkan hal serupa. ${ }^{5}$

$$
\text { Lingkungan kerja petugas }
$$
kesehatan juga dapat memengaruhi/mendorong sikap petugas kesehatan dalam menentukan perilaku penggunaan alat pelindung diri. ${ }^{18} \mathrm{Rambu}$ rambu K3 dan standar prosedur penggunaan APD yang masih perlu ditambah dan harus terpajang di semua tempat pelayanan. Informasi dan kenyamanan dalam menggunakan APD merupakan salah satu faktor yang mendukung terwujudnya perilaku penggunaan APD. ${ }^{18-20}$ 
Triningtyas, AY : Pengetahuan dan Sikap Tenaga Kesehatan..

Hasil penelitian ini sesuai dengan pendapat Green yang menyatakan sikap merupakan salah satu faktor berpengaruh (predisposing factors) yang mendorong atau menghambat individu untuk berperilaku (dalam hal ini penggunaan APD). Sikap merupakan salah satu bagian dari mengambil keputusan (decision making) seseorang terhadap risiko bahaya yang ada. Perilaku tidak selalu mengikuti urutan tertentu sehingga terbentuknya perilaku positif tidak selalu dipengaruhi oleh pengetahuan dan sikap positif. Perilaku positif yang terbentuk/didasari pengetahuan yang cukup baik dapat menetap dalam jangka waktu yang relatif lebih lama. ${ }^{6}$

\section{KESIMPULAN}

Dari hasil penelitian dapat disimpulkan bahwa sebagian besar tenaga Kesehatan di Puskesmas telah memiliki pengetahuan dan sikap yang cukup baik. Hal ini perlu mendapat dukungan dari faktor pendukung seperti fasilitas APD yang memadai, dan faktor pendorong dari pihak manajemen puskesmas supaya praktik penggunaan APD tepat sesuai standar dan berkelanjutan. Pendidikan dan pelatihan reguler diperlukan untuk mempersiapkan tenaga kesehatan tetap aman dalam memberikan layanan perawatan kesehatan terutama selama pandemi. Pelatihan prosedur APD serta praktik pencegahan infeksi merupakan implementasi target penting dari keselamatan pasien dan teknik pencegahan yang efektif.

\section{KONFLIK KEPENTINGAN}

Penulisan artikel ini tidak terdapat konflik kepentingan.

\section{UCAPAN TERIMA KASIH}

Penulis mengucapkan terima kasih kepada pihak yang telah membantu penulisan karya ilmiah ini.

\section{DAFTAR PUSTAKA}

1. Kompas.com. 10 Bulan Pandemi Covid-19 Melanda Tanah Air dan Angka Kematian Tenaga Medis yang Mengkhawatirkan. Kompas.com 03/01/2021 [Internet]. Available from:

https://nasional.kompas.com/read/20 21/01/03/07163111/10-bulanpandemi-covid-19-melanda-tanahair-dan-angka-kematian-tenagamedis?page $=$

2. Rorimpandey M, Kawatu P, Wongkar D, Diri AP, Pengelasan P. Hubungan antara Pengetahuan dan Sikap dengan Tindakan Penggunaan Alat Pelindung Diri Pada Pekerja Pengelasan di Bengkel Las Kota Menado. 2014;

3. Juita Maria Rori, Bongakaraeng MMP. Perilaku Tenaga Kesehatan 
Triningtyas, AY : Pengetahuan dan Sikap Tenaga Kesehatan..

Dengan Kepatuhan Menggunakan Alat Pelindung Diri Sesuai Standart Operating Procedure Di Ruang Rawat Inap RSUD Maria Walanda Maramis Minahasa Utara. 2017.

4. Sciences M, Gholami F, Sciences M, Sciences M. Health care personnel compliance with standards of eye and face protection and mask usage in operating rooms. 2008;13(April 2016):59-64.

5. Susiolo et al. Faktor-faktor yang berhubungan dengan kepatuhan" Virus Covid-19. 2020;7:278-84.

6. Notoatmodjo S. Pendidikan dan perilaku kesehatan. pertama. Vol. 18, Rineka Cipta. Jakarta; 2003. 19-28 p.

7. Cahyaningsih A. Evaluation of Knowledge and Compliance of Nurses on The Use Personal Protective Equipment ( PPE ) in Intensive Care Unit ( ICU ) RSUD Panembahan Senopati Bantul Yogyakarta. 2017;6(December):18793.

8. Acharya AS, Khandekar J, Sharma A, Tilak HR, Kataria A. Awareness and practices of standard precautions for infection control among nurses in a tertiary care hospital. Nurs J India [Internet]. 2013;104(6):275-9. Available from: https://pubmed.ncbi.nlm.nih.gov/249 $74532 /$

9. Kemenkes. Panduan Singkat Pelacakan Kontak (Contact Tracing) untuk Kasus COVID-19. Kementeri Kesehat RI Direktorat Jenderal Pencegah dan Pengendali Penyakit. 2020;1-23.

10. COVID-19 GTPP. Standar APD (Alat Pelindung Diri) untuk Penanganan COVID-19 di Indonesia [Internet]. Jakarta; 2020. p. 9-10. Available from: www.covid19.go.id

11. WHO. Rational use of personal protective equipment for coronavirus disease 2019 (COVID-19) and considerations during severe shortages. Who [Internet]. 2020;(April):1-28. Available from: https://apps.who.int/iris/handle/1066 $5 / 331695$

12. Sudarmo S, Helmi ZN, Marlinae L. Faktor Yang Mempengaruhi Perilaku Terhadap Kepatuhan Penggunaan Alat Pelindung Diri (Apd) Untuk Pencegahan Penyakit Akibat Kerja. J Berk Kesehat. 2017;1(2):88.

13. Puspaningrum M. Analisis Faktor Yang Mempengaruhi Tingkat Kepatuhan Penggunaan Alat Pelindung Diri Pada Pekerja Bagian Tabung Gas LPG Tahun 2016 [Internet]. Makassar; 2016. Available 
Triningtyas, AY : Pengetahuan dan Sikap Tenaga Kesehatan..

from:

https://core.ac.uk/download/pdf/7762 6374.pdf

14. Kumar J, Katto MS, Siddiqui AA, Sahito B, Jamil M, Rasheed N, et al. Knowledge, Attitude, and Practices of Healthcare Workers Regarding the Use of Face Mask to Limit the Spread of the New Coronavirus Disease ( COVID-19 ). 2020;12(4).

15. Astuti Y, Yuliwar R, Dewi N. Hubungan Tingkat Pengetahuan Dan Sikap Perawat Dengan Tingkat Kepatuhan Penggunaan Alat Pelindung Diri Di Ruang Icu, Igd Dan Irna Imam Bonjol Rsud “Kanjuruhan" Kepanjen Kabupaten Malang. J Ilm keperawatan [Internet]. 2018;3(3):663-9. Available from: https://publikasi.unitri.ac.id/index.ph $\mathrm{p} /$ fikes/article /view/1375/960

16. WHO. Penggunaan masker dalam konteks COVID-19. 2020.

17. Herdiana N. "Faktor Yang Berhubungan Dengan Penggunaan Alat Pelindung Diri Pada Perawat di Instalasi Rawat Inap RSUD Kab.Mamuju Tahun 2018 [Internet]. 2018. p. 121. Available from: http://digilib.unhas.ac.id/uploaded_fi les/temporary/DigitalCollection /ZjJjMGEyNjkxMDY0ZDQwYTg2
OTcxNzY0MGJIN2ZiNjkwMzU2N

$\mathrm{mFhYg==.pdf}$

18. PB IDI. Pedoman Standar Perlindungan Dokter di Era Covid19. 2020

19. Ditjen Kesmas Kemenkes RI. Panduan Pelayanan Kesehatan Balita pada Masa Tanggap Darurat COVID-19 bagi Tenaga Kesehatan. 2020

20. Gugus Tugas Percepatan Penanganan COVID-19. Analisa Rekomendasi Menuju Tahapan Indonesia Produktif dan Aman COVID-19. 2020 
Triningtyas, AY : Pengetahuan dan Sikap Tenaga Kesehatan.. 